\author{
Alexander Shurbanov* \\ University of Sofia \\ Sofia, Bulgaria
}

\title{
RECREATION OF THE SECOND DEGREE: UPDIKE'S SHAKESPEARE IN TRANSLATION
}

Some fifteen or sixteen years ago, as I was preparing for the translation of Hamlet, John Updike's recent prequel to Shakespeare's play, Gertrude and Claudius, was brought unexpectedly to my notice. A publisher, who had just returned from the Frankfurt Book Fair, called to ask me if I would read the novel and let her know whether it was worth translating into Bulgarian. A few days later I phoned back to say that not only would I strongly recommend the book for publication but I would very much like to translate it myself. My translation of Updike's book was published early in the next year, 2003, and my rendition of Hamlet appeared in 2006 to be staged six years later at the National Theatre in Sofia, where it is now approaching its hundredth performance. But for a few months in 2002 I had interrupted my work on Shakespeare's play to immerse myself in Updike's novel. In hindsight, it was only right to do the prelude before the main story. And so began my love affair with Gertrude and Claudius.

The task of translation is complex and problematic in principle, for it presupposes transferring a set of ideas, images, atmospheric suggestions and stylistic effects from one language into another and from one culture into another across often formidable distances in space and time. The

\footnotetext{
E-mail address: a.shurbanov@gmail.com
} 
difficulty however is raised to a higher power in cases when you have to be mindful not only of the immediate text you are grappling with but also of another, on which it is based and to which it keeps referring or alluding at all compositional and linguistic levels. At some points one is brought to the very brink of untranslatability.

What attracted me to Gertrude and Claudius in the first place was, of course, the unusual angle from which Updike looks at the Hamlet story and at its participants. Just as in Tom Stoppard's Rosencrantz and Guildenstern Are Dead (1967) and, even more so, as in Jane Smiley's A Thousand Acres (1991) or in Ian McEwan's Nutshell (2016), in this novel the perspective on Shakespeare's fictional world has been radically shifted. Here Gertrude is thrust into the limelight, not as the usual feeble-willed adulterer and possible accomplice in the murder of her husband but as a courageous feminist rebel, a new Anna Karenina, as James Schiff shrewdly observes. The prince, respectively, sinks into the background and becomes a mere spoiled, testy adolescent. As the author readily admits, "I love Gertrude, and always have... It wasn't Shakespeare who saw her as 'stewed in corruption,' it was her fastidious son."

Gertrude is definitely given the lead in the midst of a rather primitive dog-eat-dog male world. The very title of the novel prepares us for such a reshuffling: while the titles of most, if not all, Shakespeare and Renaissance plays featuring a hero and a heroine (Romeo and Juliet, Antony and Cleopatra, Antonio and Mellida) give priority to the man, ${ }^{1}$ Updike reverses the order. This radical reconstruction of the tragedy is deftly and ingeniously performed with the psychological consistency that is expected from a novel rather than from a Renaissance drama and that Tolstoy would have probably appreciated. And in spite of the radical change the prequel makes sense as an introduction to the action of the play, tinging it in an unexpected but convincing way. The significant reshuffling of Hamlet has to be sustained in any translation, but that goes without saying and is not what would give a translator pause. The devil, as always, is in the details.

1 There are, of course, exceptions to this rule, such as Marlowe's Hero and Leander and Shakespeare's Venus and Adonis. But in the first case the English title was borrowed from the poem's ancient precedent and in the second the heroine is a goddess while the hero is a mere mortal. 
From beginning to end, Updike's novel leans heavily on Shakespeare's play and strives not to break the connection to its source. This is done above all through multiple allusions to the text of the tragedy and paraphrases of various cues often confusingly redistributed. The heroine's maid Herda, for instance, echoes the memorable aphorism of Shakespeare's Hamlet, "There's a divinity that shapes our ends,/ Rough-hew them how we will", when she says in her less elegant but no less figurative way: "There's shape in things, fiddle and fuss however we will around the edges". The narrator himself does not hesitate to borrow from the original Gertrude as he describes the "little dry spicy sausages for which the peasants have an obscene name" - a culinary echo of the Queen's more romantic reference to the "long purples,/ That liberal shepherds give a grosser name". The bathetic lowering of a key Hamlet utterance ("Man delights not me - nor woman neither") is even more striking in Horvendile's paraphrase: "I take no joy in knowing that men are garbage, and women too..." Towards the end of the novel the narrator pilfers an ample excerpt from Claudius's central soliloquy (Hamlet, III, iii) to describe this character's state of mind in his own words: "His offence was rank, with the primal curse upon it. Yet whereto served mercy but to confront the visage of offense." (Note how the images and the turns of phrase are taken from the play intact, retaining the archaic, Shakespearean tone.)

In the bulk of the novel direct reproduction of Shakespeare's text is rare. Here are a few examples. Corambus (Polonius-to-be) can be heard saying: "It is not Amleth whose health seems out of joint..." - adopting Hamlet's familiar metaphor to refer to the prince's own condition. And it is the old councilor again who quotes the dictum of his dramatic prototype when he harangues not his son but the heroine this time: "Neither a borrower nor a lender be...", only to continue in the same vein with borrowings from Polonius's instructions to Ophelia, and so on. However, in the closing pages of the book, where the narrated events begin to coincide with the opening scenes of the play, Updike proceeds gradually from paraphrases to ever more extensive quotations to finally step aside and let the play take over.

This continuous and ever intensified "intertextual dialogue" of the novel with the play, to use Professor Schiff's phrase, is a hallmark of Updike's prequel and its deletion would be detrimental to any rewriting of the latter. But in order to preserve it in a translation, a frame of reference 
should be established as solid as the one provided for the English-language audience by Shakespeare's canonical text. In Bulgarian, in a little over a hundred years, we have accumulated seventeen different translations of Hamlet to choose from, and in no two of them is the wording identical. The process of translation is ongoing and the variants of the play will no doubt multiply. What can the poor translator of Gertrude and Claudius do under such circumstances but cast about for instances of proximity between the two or three currently most popular versions? And is it not clear that, whatever sleight of hand is performed, Updike's intertextual links will not be as apparent in the new environment as they are to his English-speaking readers schooled from their early days in Shakespeare's originals?

The problem becomes particularly acute when we come to the transference from the play to the novel of idiosyncratic ways of speaking used to characterize various personages. Polonius's wordy, often vacuous pomposity is a case in point. And so is Claudius's speechifying officialese. These mannerisms can, of course, be reproduced in translation with a similar suggestion of affectation or self-importance, but the intertextual connection will again be largely lost. Even so, the characterizing function of the affectation will be activated. Most inhabitants of Updike's Elsinore endeavour to express themselves in the elegant courtly style of Shakespeare's age. Gerutha/ Geruthe/ Gertrude, undoubtedly, is as skillful in using this jargon as anybody else. Here is an example of her rhetorical expertise:

I must suppose your figure of speech pertains to you and me. But I already enjoy, my lord, the protection of my father's might and believe that what you flatter me by calling beauty, possessed later rather than sooner, might ripen to my benefit and to that of my eventual consort.

The narrator himself seems to have been infected by her language and continues to emulate it in his own explanation inserted into her cue: "She went on, taking courage from her presumption of having all the valor between them". At times this studied elaboration of speech approaches the preciosity of Elizabethan euphuism with its carefully balanced constructions. Here is Gerutha again: 
But you seem to come to me conveniently, out of a general political will more than a personal desire.

Though the code of Renaissance courtly parlance is not something that all European nations can have recourse to as readily as the English, this is reproducible and can add the right sort of colour to the picture of life in Elsinore. The translator should not overlook it as a meaningful detail.

One important compositional technique suggested to Updike by his source is the system of recurrent poetic imagery that provides the thematic and atmospheric unity of each of Shakespeare's mature dramas. Animal images especially are essential to these works, and so are they to the structure and impact of Gertrude and Claudius. Horvendile (old Hamlet) is referred to as "the blond beast". His younger brother, Fengon (the future Claudius), appears as "solid as a tree, as a rigid young bear..." When the two stumble across each other, they both behave like bloodthirsty beasts fighting over a prey:

Fengon still said nothing, just kept his gaze on his brother as the King prowled, in the lofty agitation of an inescapable predator. Horvendile saw that his brother would not share the naked spoils.

And a little later, when one of them is murdered by the other, we are presented with the following simile:

Two weeks had passed since her [Geruthe's] husband had perished in the orchard, unshriven,... like some soulless little rag of a woodland prey snatched up in sharp talons.

Here Fengon is obviously associated with the falcons he breeds for hunting. The earlier murky scene of his mews throws its threatening shadow over the whole novel.

A very important element of the novel's animal imagery is that of the snarling rapacious mouths of a series of Danish kings, gradually turning into the emblem of kingship. The first in this royal succession is old Rorik: "His mouth looked meaty and twisty and red between his mustache and his uncombed, grizzled beard." Then comes Horwendil/ Horvendile/ King 
Hamlet with his "confident laugh... exposing short, neat, efficient teeth". But the portrait of Feng/ Fengon/ Claudius is the most prominent and most interesting of all: "His teeth were irregular but seemed strong and all in place." And again: "Feng laughed, his teeth uneven but thrilling in that red mouth, there between his triumphant mustache and pointed Italianate beard." Later we hear that "... he arrived erect and mussed in the room, his wolfish teeth sheepishly grinning in his speckled oval beard". And we are reminded again of the irregularity of his teeth, often described as "wolfish", with a focus on his sharp canines.

In contradistinction to the predatory maws of the kings, Corambus's mouth looks more like that of a sheep: "... he had one of those wet lower lips that appear slightly out of control, spraying softly on certain sibilants, drifting to one side or another when relaxed." This tell-tale feature of the old councilor is brought back to our notice as often as he appears on the scene.

His daughter Ophelia's lips and teeth, though markedly different, are also manifestly in view:

The girl had a lovely upper lip, turned both inward and outward like a plucked rose petal, slightly crumpled by the infusion of sweet plumpness, and it was fetching, Gertrude thought, the way it rested tentatively closed on the lower, leaving an open triangle through which her teeth dimly gleamed.

Here the aggression of the strong men is replaced by erotic lure. Gertrude, is also revealed by a telling glimpse of her mouth:

Had her beauty a flaw, it was a small gap between her front teeth, as if too broad a smile had once pulled the space forever open.

Gap-tooth has, of course, been traditionally considered a sign of sensuality and lust in women. It was Chaucer's Wife of Bath who once said:

But yet I hadde alwey a coltes tooth.

Gat-tothed I was, and that bicam me weel,

I hadde the prente of Seinte Venus seel.

As help me God, I was a lusty oon...

The image patterns in the novel are pervasive and intricately woven. These thematic chains should be detected and diligently reproduced in translation without fail. 
Imagery or figurative language in general is the universal hallmark of poetry. Updike was a born poet and his lyrical predisposition is apparent in his prose too, where descriptive details often burgeon into genuine evocative tropes like the following: Denmark with its archipelago of tiny islands is visualized as "a realm, scattered and jagged like the broken earthenware of a dish just fallen to the floor"; Gerutha in her undress is "as white as an onion, as smooth as a root fresh-pulled from the earth"; and in her pregnancy, she poses for us naked again, "her beautiful swollen belly veined with silvery stretch marks"; the horse's ear appears unexpectedly in vivid prurient close-up from the point of view of the rider with "its hairy exterior perked, its interior lilylike and a tint akin to human flesh".

A fascinating detail crops up in the very beginning of the book to render the scene of medieval Denmark vibrantly palpable:

Rorik was entertaining his daughter within a small timberfloored and wainscoted oriel room recently built to adjoin the King's bedroom, in this perpetually revised old castle of Elsinore. Lozenges of red afternoon sun lay on the broad planks of oiled fir, making good the designation of "solar" for these upper chambers devoted to private residence within a castle.

And a similar description of another, ceremonial room in the same building is sketched out in the last pages of the novel:

The day was revolving overhead, dropping rhomboids of sun upon the multi-colored finery and the hall's broad oak planks, worn and scarred.

This recurrent radiant indoor scene, providing a strongly visual impression of Gerutha's abode and reflecting on her character, is in turn a reflection from a much earlier Updike novel. In Of the Farm the narrator, who has returned to his parents' home after long absence, wakes up in the morning to find out that he has reentered the glowing world of his childhood:

Downstairs, on the tawny kitchen floorboards scuffed and scored by dog claws, there lay, like a papery golden mat spread before the front door that gazed with its single large pane through the grape arbor toward the meadow, a rhomboid of sun mottled with 
the slightly shivering shadows of grape leaves. This patch of sun had been here, just this shape, twenty years ago, morning after morning.

I cannot help thinking that the vivid picture of the sunlit wooden floor is indeed one of the author's earliest memories that keeps returning in his fictional worlds over the span of four decades. ${ }^{2}$ The new readers of Updike's Shakespearean novel should be drawn to it in a similar magical way. All it takes to achieve this is the delicacy of a painterly touch in the use of language. A good translator would know how to apply it.

Even stark abstract notions become strongly palpable in Gertrude and Claudius the way they often do in Shakespeare's poetic masterpieces, such as Macbeth's soliloquies or Sonnet 66 ("Tired with all these, for restful death I cry..."): "days of hurtling sun and shade like the dapples of an exhilarated beast"; "my own conscience grimaces at the least action that is not queenly"; "she had mounted to an eminence of abandon"; "they hesitated at the edge of the incestuous crime yawning at their feet"; "she could not stop seeking for what, elusively, was amiss in their circumstances, like a skipped stitch that might unravel the whole sleeve". At times the images are radicalized into strained catachresis, similar to those of metaphysical poetry - figures of a kind not shunned by Shakespeare himself: "as water will stand up in globules on a fresh-waxed table or on newly oiled leather, so her love, as she felt it, spilled down upon Amleth and remained on his surface, gleaming like beads of mercury, unabsorbed".

Play on words is also almost as characteristic of Gertrude and Claudius as it is of Hamlet: "your wise sweetness, or sweet wisdom..."; "though base, you have no base, mine is as wide as Denmark". In the process of translation, each of these figures has to be treated with minute attention, for the message of an artistic work is contained as much in its formal structuring as in its semantic content.

2 As Prof. Donald Greiner informs us, Updike revised Of the Farm for a new, Ballantine edition, which was going to be published in 2004. If he had already begun thinking about the revision of his early novel while working on Gertrude and Claudius, some details of the former may have unintentionally flowed into the latter. 
Updike's poetic mindset surfaces also in his penchant for alliteration, a device that moulds every page of his prose, starting from the very titles of his serial novels: Rabbit, Run; Rabbit Redux; Rabbit Is Rich; Rabbit at Rest; Rabbit Remembered; Bech, a Book; Bech Is Back; Bech at Bay. It is not that this is uncommon in English-language literatures, but Updike's insistence is rather exceptional. Alliteration seems to be a constant feature of this writer's work: only very few of his novels, such as Villages and Toward the End of Time, are relatively free of it, and it is as if the author has for some reason made a special effort to avoid phonetic repetition in them. But even in such a context, the alliteration in Gertrude and Claudius is unusually dense. This may be due to Updike's desire to emulate Shakespeare's poetic style or to imitate the embellished aristocratic language of the Renaissance. The reader will often come across intense series of recurrent sounds as in: "Fengon's slightly sinister gift had enlisted her in a secret of sorts"3; "I was my father's daughter, and became the wife of a distracted husband and the mother of a distant son"; "... to put the seal on the solitude and secrecy I seek"; "Geruthe laughed at her fickle, flattering feelings"; "... in a tumble of furs, that tingled and tickled and were tucked tight around her". Sometimes the alliterative scheme weaves together two or more different sounds, the way Shakespeare is so skillful in doing: "she and Horwendil were fixed in place like figures beaten in brass or else overanimated like actors, dancing through sheets of candlelight and forests of food"; "the mark of shame and malice my hired tongues set upon you will make your murderer a hero"; "her gaze greeted, through the two-pillared window of her solar, the bile-colored Sund and the bleak beckoning strip that was Scåne"; "the impression at any rate was unpleasant, and Claudius, cautiously nodding in response, made a mental note that his Lord Chamberlain's retirement must be arranged". This complexity of interlaced sound patterns is reminiscent of the intricate embroidery of Renaissance tapestries. Even when not functionally related to meaning it nonetheless creates the impression of something opulent and lush, immersing us in the courtly aestheticism of the age.

Quite often though the alliterative effect has a rhetorical purpose as in the emphatic constructions: "I have trimmed my feelings to suit the demands of Denmark", or "She ascribed all this to the good cause of stifling chaos in

3 Emphasis added throughout. 
the wake of calamity". Like Shakespeare winding up an important speech, episode or scene with a rhymed couplet, Updike strikes his final alliterative chords to mark an important moment or a grave pronouncement: "to keep a secret from the King is treason, the most capital of crimes"; "only ignorance will keep her heart and countenance clear"; "my brother was right - the Lord Chamberlain is ripe for retirement".

The translator is hard put to it to render faithfully this important stylistic, atmospheric and tonal level of the novel's text. In a language and culture that have relied on alliteration considerably less than the English tradition has, overloading the narration with dense repetition of identical phonemes would be counterproductive. On the other hand, to ignore alliteration altogether would mean to impoverish the texture of the book and deprive it of much of its poetic brilliance. As usual, the art of translation boils down to thoughtful and sensitive compromise.

As Donald Greiner puts it, John Updike is "an artist of the highest order". His ability to create a new language to suit the central preoccupation of each of his novels is truly astounding. The register in which Gertrude and Claudius is written is clearly raised above the colloquial level and it keeps the audience at an arm's length - quite different in this respect from the Rabbit novels. Each of the three parts of the Hamlet book starts with the refrain "The King was irate", setting from the first line the formal tone of the narration. The studied abstract language of generalizations strives to drown in its cerebral element all concrete observations and actions. This is how the narrator usually speaks:

They would talk, many a time of their growing daughter, the radiant fruit of one such clipping - the child's piecemeal assumption of mobility and speech, the dropping away of treasured mispronunciations and lisped coinages as she gathered to herself more correct language and adult manners.

Here, in their own, more modest castle, they advanced with more caution, without the King's paternal protection, attempting to domesticate the outrage their bodies were plotting.

The characters tend to express themselves in much the same rarefied conceptual manner. 
Horvendile: Hamblet's attachments are not sentimental affairs, but matters for deliberation in the most dispassionate counsels.

Geruthe: I recovered a measure of contentment and resignation in my virtual solitude.

The choice of vocabulary is, of course, the main factor for the achievement of this insistent heightening of diction. The predominance of abstract notions is an important part of the author's choice. In addition, Updike uses some rare words and phrases like "the gibbous moon", "motherlessness", "marmorial gloss"; historicisms of the sort of "miniver", "surcoat", "cotte", "camise", "houppelande", "cotehardie", "brigandine", "gisarme", "glaive", "halbert", "råd", "thing", "portcullis", "barbican", "bailey", "garderobe", "solar", "flagon". His study of the twelfth-century setup in dress, armament, architecture, way of living, administration, etc. is patently scholarly. As John Bailey rightly remarks, Updike surpasses other modern rewriters of Hamlet in "historical weight and sobriety". Gertrude and Claudius displays almost professional knowledge of old crafts and sports with their special terminologies and jargons. The author's proficiency in the art of falconry is especially stunning as he makes Feng introduce Gerutha to the different kinds of hunting birds and the ways they are trained, apologizing for what may seem pedantry to her, but warning her that in this craft "there is a science of sorts that insists on its own nomenclature". And indeed, it is a full-fledged science as becomes clear in the important mews scene. Feng introduces each bird as representative of its kind and function, piling up terms like "tiercel", "eyas", "passager", "haggard", "gyrfalcon", "peregrine", "sparrow hawk", and adding words about their upkeep and breeding: "creance", "jesses", etc. Gerutha may have heard many of these, as she confidently affirms, but most of these notions were new to the Bulgarian translator and would hardly ring a bell to the readers of his translation. Falconry is an aristocratic sport and the Bulgarian aristocracy was decimated by the Ottoman invasion. Little linguistic trace of its culture has survived. Other strands of abstruse terminology include "ductia", "stem stitch", "split stitching", "recorders", "cloisonné pendant", "clerestory windows", "lancet windows", etc., lexical items for which more often than not no dictionary equivalents can be found in the language of a country with a history very different from that of Western Europe.

Obsolete or obsolescent words and phrases, some of them borrowed from Shakespeare, are also employed to give the narration the right feel of 
a bygone age and further aggravate the translator: "fêted", "porpentine", "bodkin", "politic", "countenance", "plight troth", "put asunder" (the last two felt even by Gertrude to be "archaic"). There are also quite a few foreign-language insertions from Provençal, Latin, Greek, French, Italian, Spanish, German and Old Danish sources. To these should be added around forty Scandinavian toponyms and two dozen personal names, many of them drawn from Northern legends and mythology and often as unpronounceable and untranscribable as Jörmunrekr, Svanhildr, Yggdrasil. I had to write to the American publisher of Gertrude and Claudius, Alfred A. Knopf asking for clarification about some of these items. And lo and behold, a very kind and helpful personal typewritten letter from the author himself came one day to my doorstep in Sofia - something that could not have happened, unfortunately, while I was toiling over Shakespeare's work. But more of that, a little later. Let me just say at this point that I felt obliged to compile for the Bulgarian edition a list of 78 explanatory notes, some of them fairly extensive.

The highly literary, slightly antiquated register of Updike's novel is achieved in a variety of ways besides the careful choice of vocabulary. One of these is the elegant variation of reporting verbs accompanying direct speech. While in contemporary English-language writings the use of such verbs is usually reduced to the basic "s/he said" and (less often) "s/he replied", here we are regaled with a much wider choice of synonyms with the occasional addition of extended pointers to the attitude, mood and tone of the speaker: "Geruthe agreed", "allowed Fengon", "she asked", "he began", "he joined her in banter", "Corambis prompted", "she made herself go on", "she hurried on", "the Lord Chamberlain decided", "he sighed", "she laughed in turn", "she shuddered", "he explained", "she answered in offended kind", "said Fengon, in his soft, on-running voice", "she said, rather loftily", "he observed, but tentatively, as if willing to be contradicted", "Corambis insisted gently", "Fengon distractedly explained", "she commanded him", "the Queen admitted", "Fengon warned", "he exclaimed", and so on. Such stylistic latitude is indeed rather exceptional in English prose nowadays and it was perhaps employed to create both a slightly dated style and a heightened atmosphere, but as it is less unusual in contemporary Bulgarian literature, the effect of the author's technique will inevitably be reduced in 
the process of linguistic transference. This is one of the irreparable losses in translation, due to the lack of symmetry between languages and their uses, and the only way of minimizing it would be to try and compensate for it elsewhere.

The syntactical structure of the novel is particularly important to consider in this context. In another of his later works, Villages, Updike mentions "... four children nosing ahead like earthworms in the world's substance, encountering pebbles like bad school reports and the deaths of pets, but pushing on, growing, speaking in ever more complete and complex sentences". Maturity for this writer is, obviously, manifested in the mastering of language and above all in the command of its intricate logical organization, the ability to pack in a single sentence a great chunk of experience and thought. Long complex periods are what he endeavoured to create and control from his earliest novels on, yet their incidence in Gertrude and Claudius is unusually high. Here is a rather typical example of narration from the opening section of the novel:

The quiet hoops and tops and dolls of Gerutha's girlhood had no place in this male world of projectile fantasy, of hits and thrusts and "getting even" - for a strict tally was kept in the midst of all the shouts and wrestling, she observed, as in the bloodier accountings of adult warfare, much as Horwendil boasted of how King Fortinbras, in being slain, had forfeited not only the invaded terrain in Jutland but certain coastal lands north of Halland on the coast of Sweathland, between the sea and the great lake of Vänern, lands held not for their worth, which was little, but as a gall to the opposing power, a canker of dishonor.

It is amazing how far we have journeyed from the beginning to the end of this meandering sentence across a whole bustling world of event-filled geographical expanses. Another sprawling, enumerative sentence with clusters of subordinate clauses that bulge out at every point, starting with the words "O the days, the days..." and running through some forty lines, is meant to fill the time-gap of Fengon's long absence from Elsinore in a manner similar to that in which Time's choric speech bridges the hiatus of sixteen years in the middle of Shakespeare's The Winter's Tale. Yet another 
sentence traces the entire technological process of the production of silk and its uses from the cocoon to the richly decorated tunic, and a later one roams with Gertrude through the vast castle taking account of the details of its rambling structure.

The complex sentences in Gertrude and Claudius are of various kinds, but the predominant type is the one including substantial, and often branching out, parenthetical components as seen in the following example:

Her own name too, the rare times he heard it issue from her lips - for our names are used for convenience by others but figure marginally in our own minds, which know ourselves as an entity too vast and vague to name - was softened to "Geruthe".

Occasionally constructions of this type develop into long periodic sentences with multiple ramifications striving to follow each separate turn of a complex argument:

Thus isolated, visited only by Herda, who had her own reasons for grief, for Sandro was gone and her belly was swollen, and by her whispering ladies-in-waiting, whose faces were rapt with the thrill of the recent horrific event, and the castle physician, with his dropsical bagcap and bucket of writhing leeches, Gertrude played doctor to her own spiritual symptoms, wondering why her grief felt shallow and tainted by relief.

Although such structures are not confined to this particular novel, I suspect that their accumulation here is due to the author's attempt to cultivate a way of speaking similar to that of the inhabitants of Hamlet's Elsinore and above all of the prince himself in monologues such as the "Ay marry is't" in I, iv:

So oft it chances in particular men

That for some vicious mole of nature in them,

As in their birth, wherein they are not guilty

(Since nature cannot choose his origin),

By their o'ergrowth of some complexion,

Oft breaking down the pales and forts of reason,

Or by some habit, that too much o'erleavens

The form of plausive manners - that these men,

Carrying, I say, the stamp of one defect,

Being Nature's livery or Fortune's star,

His virtue else, be they as pure as grace, 
As infinite as man may undergo,

Shall in the general censure take corruption

From that particular fault.

Naturally, such heavy syntax can pall on the reader, so time and again Updike breaks through it with sudden outbursts of energetic short sentences when a decisive action or an intense emotional state of a character calls for such a change, as in the following account of Horvendil's descent to his death in the fatal orchard:

The King emerged from the arched opening at the base of the bailey wall. His robes were brilliant in the low slant of sunshine. His face looked bloated and weary, naked in its ignorance of being observed.

Or, even more noticeably, in a later cue of Gertrude:

I am his mother, yes. I know him. He is cold. You are not, Claudius. You are warm, like me. To my son, everything is mockery, a show. He is the only man in his universe...

One might wish that these breaks had been more frequent, but as the writer is intent on sustaining his staple tone, translators would do well to respect this choice and resist the temptation to make Updike's lengthy sentences more palatable by segmenting them into shorter and simpler fragments.

It can be concluded that Gertrude and Claudius is closely related to Hamlet on many levels of its structure over and above the story itself. And if the novel reinterprets the action of the play and its participants in a fairly radical way (an approach that, incidentally, was characteristic of both Marlowe and Shakespeare in their dealings with classical lore), in the use of language it follows its model quite faithfully. Translators should be aware of this lifeline between the old text and the new and should try to sustain it. In my particular case, I was fortunate to have been long immersed in Hamlet both as teacher and translator before starting work on its prequel. It was my luck too to be able, on this occasion, to engage in correspondence with at least one of the two authors I was dealing with and to, quite unexpectedly, receive from him not just an explanation of several 
dark places in his text but also an important addition of a few sentences in the closing section of the novel, which, as Professor Greiner has pointed out, is important for the central message of the work because it amounts to Gertrude's final exoneration:

She was happier wed. Like a broad-beamed ship she lightly rode in the safety of harbor. Her venture into the defiance and protest of adultery had been, like his years of southern wandering, an excursion, an exploration of her nature that, its question settled, need never be resumed.

The inclusion of this definitive comment on the heroine's character in my translation did make the Bulgarian version of Gertrude and Claudius, as Updike himself wrote to me, "the most authoritative foreign edition" of the novel and, in fact, even a more complete one than the original American edition, to be equaled in this respect for the English-speaking world only a decade later. It seems to me that Updike made this special gift to commemorate his romance with the "Bulgarian Poetess", whom he briefly met in Sofia back in 1964 and had not forgotten for the intervening almost forty years. Bulgaria had not forgotten him either. Whereas he was virtually unknown in my country when he happened to visit it, seventeen of his novels and a collection of short stories have been published and republished since then in Bulgarian translation. In the year of the publication of my translation of Gertrude and Claudius Blaga Dimitrova died at the age of eighty-one. Six years later, in 2009, I was asked by a Sofia paper to write an obituary for John Updike. A generation of important writers divided by the Iron Curtain and defying this ignominious division through their dedication to the higher principles of their art, was inevitably becoming, together with its period, part of the past.

Younger writers both east and west have a lot to learn from this brave and gifted generation. In his writing John Updike demonstrates the highest kind of professionalism that his younger colleagues would do well to emulate. His perfectionist care for the uses of language, the fine sensitivity to stylistic modulation, the ability to move with grace in an intertextual medium and spark off meanings at every turn are the distinctive qualities of his best work. And so is the meticulous study of the life material from which his literature arises.

It is sad that the bulk of critical attention devoted to Updike is confined to the Rabbit novels, with which he first came to public notice. 
When, a year after the publication of my translation of Gertrude and Claudius, I happened to teach at a US University and mentioned this novel to a colleague conducting a course on literature and intertextuality, I was surprised to hear that she knew about the book but had not thought of including it in her syllabus. On my suggestion, she eventually did so, and was satisfied by the stir this addition created among the students. Such thoughtful rewritings of the classics are just the kind of stuff that can develop and broaden young minds in their explorations at the interface of old and new periods of literary history. For every rewriting of an immortal work is an act of its creative criticism and rejuvenation.

\section{References}

Bayley, J. (2000). It Happened at Elsinore. New York Review of Books, Vol. 47, No. 5, 13-15.

Chaucer, G. (1965). The Canterbury Tales, From the Text of W. W. Skeat. London: Oxford University Press.

Greiner, D. (2014). Updike Revised: The Authoritative Edition of Gertrude and Claudius. The John Updike Review, Vol. 3, No. 1, 1-14.

McEwan, I. (2016). Nutshell. London: Jonathan Cape.

Schiff, J. (2014). Two Neglected Female-centric Novels of Updike's Late Phase: Gertrude and Claudius and Seek My Face. The John Updike Review, Vol. 3, No. 1, 45-63.

Smiley, J. (1991). A Thousand Acres. New York: Alfred A. Knopf.

Stoppard, T. (1967). Rosencrantz and Guildenstern Are Dead. London: Faber \& Faber.

Updike, J. (1965). Of the Farm. New York: Faucett Books, Alfred A. Knopf. Updike, J. (2000). Gertrude and Claudius. New York: Alfred A. Knopf.

Updike, J. (2011). Higher Gossip. Essays and Criticism. New York: Alfred A. Knopf.

Шекспир, У. (2006). Хамлет, Превод от английски: Александър Шурбанов. София: Просвета.

Ђпдайк, Д. (2003). Гертруда и Клавдий, Превод: Александър Шурбанов. София: Прозорец.

Received: 14 August 2018

Accepted for publication: 28 December 2018 